\section{Tolerance to Virulence Phenotypes of Phytophthora capsici in Pasilla Pepper Cultivars}

\author{
Alfredo Reyes-Tena \\ Instituto de Investigaciones Agropecuarias y Forestales, Universidad \\ Michoacana de San Nicolás de Hidalgo, Km. 9.5 Carretera Morelia- \\ Zinapécuaro, 58880 Tarímbaro, Michoacán, Mexico; and Instituto de \\ Investigaciones en Ecosistemas y Sustentabilidad, Antigua Carretera a \\ Pátzcuaro 8701, Col. Ex Hacienda de San José de la Huerta, 58190 \\ Morelia, Michoacán, Mexico
}

Gerardo Rodríguez-Alvarado

Instituto de Investigaciones Agropecuarias y Forestales, Universidad Michoacana de San Nicolás de Hidalgo, Km. 9.5 Carretera MoreliaZinapécuaro, 58880 Tarímbaro, Michoacán, Mexico

José de Jesús Luna-Ruíz

Centro de Ciencias Agropecuarias, Universidad Autónoma de Aguascalientes, Av. Universidad 940, 20131, Aguascalientes, Mexico

Viridiana Arreola-Romero

Universidad Tecnológica de Morelia, Vicepresidente Pino Suárez 750, 58200, Morelia, Michoacán, México

\section{Kirsten Lizeth Arriaga-Solorio, Nuria Gómez-Dorantes, and Sylvia P. Fernández-Pavía \\ Instituto de Investigaciones Agropecuarias y Forestales, Universidad Michoacana de San Nicolás de Hidalgo, Km. 9.5 Carretera Morelia- Zinapécuaro, 58880 Tarímbaro, Michoacán, Mexico}

Additional index words. Capsicum annuum, landraces, pepper wilt, severity, specific tolerance

Abstract. Phytophthora capsici is the most important limiting factor in the production of chile pepper in Mexico. This pathogen presents virulence phenotypes capable of infecting diverse cultivars of this crop. The search and development of resistance in chile pepper is an excellent alternative for the management of $P$. capsici. The objective of this work was to evaluate the response of four pasilla pepper cultivars to infection with five virulence phenotypes of $\boldsymbol{P}$. capsici. Pasilla pepper landraces PAS-1, PAS-2, PAS-3, and PAS4 were inoculated with $P$. capsici isolates MX-1, MX-2, MX-7, MX-8, and MX-10. Two experiments were conducted under greenhouse conditions from April through June 2017 and April through June 2018. 'California Wonder' was included as a susceptible control, and uninoculated plants were included as a negative control. In each experiment, groups of six 56-day-old plants from each pepper cultivar were inoculated with each virulence phenotype. Disease severity was evaluated 20 days after inoculation using an individual plant severity scale. All pepper cultivars were classified as resistant $=\mathbf{R}$, moderately resistant (MR), tolerant (T), moderately tolerant (MT), or susceptible (S), according to the frequency of resistant plants (severity 0-1). 'California Wonder' and 'PAS-4' were susceptible to all five virulence phenotypes. The rest had different responses to the virulence phenotypes, but 'PAS-2' and 'PAS-3' were susceptible to only one of the five virulence phenotypes. Pasilla peppers with low severity exhibited a slow rate of infection, which is a mechanism we have called "slow wilting." The pasilla pepper cultivars PAS-1, PAS-2, and PAS-3 could be used in plant breeding programs as sources of genetic tolerance and moderate resistance against $P$. capsici.

Chile pepper (Capsicum species) is of great economic, social, and scientific importance in Mexico, which is a country with a high level of diversification of cultivars and history of domestication of this Solanaceous crop (Aguilar-Rincón et al., 2010). During 2019 , the production of pepper surpassed 3 million tons, placing Mexico among the
Mexico. Different landraces (farmers or local cultivars) of pasilla peppers are cultivated in north-central Mexico (Durango, Zacatecas, Aguascalientes, San Luis Potosí, Guanajuato, Querétaro, and Michoacán). Pasilla peppers are commercialized and consumed as dried chiles to prepare moles; however, they are sometimes harvested and commercialized unripe (known as "Chilaca" peppers). The fruit is 15 to $20 \mathrm{~cm}$ long and 2 to $3 \mathrm{~cm}$ wide (Muñoz, 2000), but it can be as large as 34 $\mathrm{cm}$ long and $5.6 \mathrm{~cm}$ wide (Rincón et al., 2010). Immature fruits are deep dark green and turn to blackish brown at maturity. Once dried, fruits are moderately spicy and present a shiny and wrinkled surface similar to a "pasita" (raising), which explains its common name "pasilla" (Muñoz, 2000).

The most important factor that limits the production of this crop in most areas of the country and in other producing countries, however, is the disease Phytophthora blight caused by the oomycete $P$. capsici (Barchenger et al., 2018a; Leonian, 1922; MacíasValdez et al., 2010; Silva-Rojas et al., 2009), which can cause up to $100 \%$ of losses (Barchenger et al., 2017). P. capsici can attack different parts of the plant and produce different syndromes, including rot of the root, crown, stem, and fruit (Jiang et al., 2015; Monroy-Barbosa and Bosland, 2010, 2011; Oelke et al., 2003; Reyes-Tena et al., 2019; Ribeiro and Bosland, 2012; Sy et al., 2008). Furthermore, this oomycete is a highly destructive pathogen with a wide range of economically important crops (Lamour et al., 2012b).

The high genetic diversity reported in populations of $P$. capsici in central Mexico (Castro-Rocha et al., 2016) increases the capacity of this pathogen for adaptation to changing environments. Furthermore, the loss of heterozygosity in $P$. capsici populations has been reported as an allele fixation mechanism that favors rapid adaptation to new hosts and the emergence of new genotypes (Lamour et al., 2012a). The control of $P$. capsici is complex because of the presence of different virulence phenotypes. Phenotyping for virulence is determined by evaluating the resistance or susceptibility of differential pepper lines against different isolates of this oomycete (Barchenger et al., 2018b). Fungicides, solarization, and crop rotation practices have been ineffective (Barchenger et al., 2018a; Bi et al., 2014). Therefore, the search and development of pepper cultivars resistant to local isolates and virulence phenotypes of $P$. capsici are the best alternative to manage this destructive disease (Foster and Hausbeck, 2010; Reyes-Tena et al., 2019). In addition, host resistance is an environmentally friendly strategy that can reduce the application of pesticides (Barchenger et al., 2017). Six major chromosomal regions related to resistance to $P$. capsici have been reported for Capsicum annuum (CastroRocha et al., 2012); however, understanding this interaction is complex because resistance to $P$. capsici is regulated by several unknown genes (Barchenger et al., 2018a).

Mexico is an important reservoir of genetic variations of chile peppers, particularly of 
C. annuum (Aguilar-Meléndez et al., 2009; Aguilar-Rincón et al., 2010), where many of the Mexican landraces used in traditional agriculture are resistant or tolerant to $P$. capsici. These peppers could be a source of germplasm for the development of improved cultivars with resistance to $P$. capsici (GómezRodríguez et al., 2017; Palma-Martínez et al., 2017; Retes-Manjarrez et al., 2020). Selection and purification of landraces with resistance or tolerance to different virulence phenotypes could help in the development of improved cultivars for direct use by local producers. Therefore, the objective of the present study was to evaluate the response of four landraces of pasilla peppers from the states of Aguascalientes, Michoacán, and Zacatecas against five virulence phenotypes of $P$. capsici.

\section{Materials and Methods}

Phytophthora capsici isolates. The isolates used in this study were virulence phenotypes MX-8, MX-10, MX-7, MX-2 and MX-1. They were recovered from chile pepper plants showing typical signs of wilting and rot root in commercial fields of Copándaro (MX-8), Morelia (MX-10), Queréndaro (MX-1 and MX-2), and Tarímbaro (MX-7) in the state of Michoacán. The virulence phenotypes were tested on the New Mexico Recombinant Inbred Lines (NMRILs). The level of virulence was higher on the phenotypes MX-1 and MX-2, and the phenotype MX-10 showed the lowest virulence on the lines tested. All isolates were previously characterized morphologically and molecularly (Reyes-Tena et al., 2019, 2020).

Plant material. The landrace cultivars of pasilla chile pepper (C. annuum) evaluated during this study were pasilla-1 (PAS-1), pasilla-2 (PAS-2), pasilla 3 (PAS-3), and pasilla 4 (PAS-4). They were collected from pepper-producing areas in the following municipalities: Queréndaro, Michoacán (PAS4); Ojo Caliente, Zacatecas (PAS-2); Pánfilo Natera, Zacatecas (PAS-3); and Rincón de Romos in Aguascalientes, Mexico (PAS-1). California Wonder (CW), a sweet pepper commercial cultivar was used as a susceptible control. This cultivar has been used as a standard susceptible control against $P$. capsici (Candole et al., 2012). Sufficient seedlings per cultivar were produced in cell trays of 100 $\mathrm{cm}^{3}$ per cell filled with commercial substrate (Mix 3 Sunshine; Sun Gro Horticulture, Agawam, MA). All seedlings were watered at field capacity every $48 \mathrm{~h}$ and fertilized once per week with Miracle-Gro (24N-8P-16K).

Received for publication 14 May 2021. Accepted for publication 13 July 2021.

Published online 25 August 2021.

A.R.-T. thanks the National Council of Science and Technology (CONACyT) for doctoral study grant 429123.

S.P.F.-P. is the corresponding author. E-mail: patricia.pavia@umich.mx.

This is an open access article distributed under the CC BY-NC-ND license (https://creativecommons. org/licenses/by-nc-nd/4.0/).
Table 1. Classification of pepper cultivars according to the frequency of resistant plants.

\begin{tabular}{lcc}
\hline Classification & Category & $\begin{array}{c}\text { Resistant plants } \\
(\%, \text { severity } 0-1)\end{array}$ \\
\hline Resistant & R & $>90$ \\
Moderately resistant & MR & $61-90$ \\
Tolerant & T & $41-60$ \\
Moderately tolerant & MT & $30-40$ \\
Susceptible & S & $<30$ \\
\hline
\end{tabular}

Inoculation. Plants of each cultivar that were $56 \mathrm{~d}$ old were inoculated with the pathogen. Uninoculated plants of each cultivar were used as a negative control. The inoculation procedure was performed as described by Reyes-Tena et al. (2019), with minor modifications. When abundant sporangia formation was observed, all isolates received a low temperature shock $\left(4^{\circ} \mathrm{C}\right.$ for $\left.30 \mathrm{~min}\right)$ to induce the release of zoospores. A zoospore suspension of each isolate was adjusted to $1 \times 10^{4}$ zoospores $/ \mathrm{mL}$. Each plant received $1 \mathrm{~mL}$ of inoculum at the stem base using a 5-mL dosing syringe (Ape).

Registered variables. All plants were evaluated according to the severity scale described by Glosier et al. (2008). This scale comprises six levels of severity as follows: $0=$ no symptoms (healthy plant); $1=$ chlorotic leaves without necrosis on the stem; $2=$ minor stem necrosis; $3=$ moderate stem necrosis and early foliar wilt; $4=$ severe stem necrosis and leaf wilt; and $5=$ plant death caused by necrosis and wilting. The evaluation of severity was performed $20 \mathrm{~d}$ after inoculation (dai), when the susceptible control reached a severity level of 4 or 5 . The pathogen was re-isolated from susceptible plants (severity $>3$ ) and from tolerant plants with necrotic root tips (severity $=1$ ) to verify its presence. The pepper cultivars were classified into five categories (Table 1) according to the percentage of resistant plants.

Experimental design. A completely randomized $6 \times 5$ factorial design with six replicates was used (Reyes-Tena et al., 2019). The design included six levels of the pathogen (five virulence phenotypes of $P$. capsici plus an uninoculated control) and five pepper cultivars (four of the pasilla-type plus the CW susceptible control). This combination yielded 30 treatments or combinations between the six phenotypes of the pathogen and the five cultivars of the host. Six replicates (plants) were used per combination and randomly distributed, yielding a total of 180 experimental units. The experiment was conducted from April through June 2017 and repeated in April through June 2018.
Statistical analysis. The severity data of each experiment were analyzed independently. The homoscedasticity test of variances was not significant $(P>0.05)$; therefore, a combined analysis was performed using a single data matrix of both experiments from 2017 and 2018. A two-factor analysis of variance (ANOVA) was used to analyze the interaction between the phenotype of the pathogen and the host cultivar. The independent response of each cultivar to the phenotypes of the pathogen was analyzed using a one-way ANOVA. For specific comparisons between treatments, Tukey's test was applied. Statistical analyses were performed with the Statgraphics Centurion XVIII statistical package. In all cases, significant effects were considered when $P \leq 0.05$.

\section{Results}

All CW plants (susceptible control) showed the typical symptoms of the disease (stem and root necrosis, chlorosis, and foliar wilt) when inoculated with each one of the five virulence phenotypes of $P$. capsici. Gradually advanced severity was observed starting at 3 dai. The severity of the uninoculated cultivars was 0 ; therefore, the positive and negative controls behaved as expected in the two experiments. Each pasilla chile cultivar evaluated had the same resistance/susceptibility reaction to the different isolates of $P$. capsici tested in the 2 years of evaluation.

The factorial ANOVA is shown in Table 2. The factorial ANOVA detected statistically significant effects for the pathogen-host interaction (Tables 2 and 3). This significant hostpathogen interaction indicates that the disease severity depends on the specific combination of the virulence phenotype of the pathogen and the cultivar of the pepper.

When the response of each cultivar of pasilla pepper to the five phenotypes of the pathogen was analyzed, significant differences $(P<0.05)$ were observed in the level of severity for all except CW (Table 3). In the case of the susceptible cultivar $\mathrm{CW}$, all the isolates caused similar but high levels $(>3)$ of severity $(P>0.05)$, thus confirming the susceptibility of CW to $P$. capsici. The PAS-1 cultivar registered a level of damage statistically similar to that of the control without inoculum against the MX-1, MX-7, and MX-10 phenotypes of $P$. capsici. During other experiments involving three virulent isolates from central Mexico, this cultivar showed tolerance with $>80 \%$ of asymptomatic plants as well as higher values of dry biomass and root volume than the positive controls (unpublished data). The cultivar

Table 2. Two-way analysis of variance of severity data on pasilla pepper cultivars uninoculated or inoculated with five virulence phenotypes of Phytophthora capsici.

\begin{tabular}{llrrr}
\hline ANOVA & \multicolumn{1}{c}{ Source of variation } & df & \multicolumn{1}{c}{ F } & $P$ \\
\hline Factorial & Virulence phenotype & 5 & 23.15 & 0.000 \\
& Pepper cultivar & 4 & 11.90 & 0.000 \\
& Virulence phenotype $\times$ chile cultivar & 20 & 2.24 & 0.000 \\
& Experimental error & 253 & & \\
\hline
\end{tabular}


Table 3. Severity of Phytophthora blight on five pasilla pepper cultivars uninoculated (control) or inoculated with five virulence phenotypes of Phytophthora capsici.

\begin{tabular}{lllllll}
\hline & \multicolumn{7}{c}{ Severity of disease } \\
\cline { 2 - 7 } Virulence phenotype & MX-1 & MX-2 & MX-7 & MX-8 & MX-10 & Control $^{\mathrm{x}}$ \\
\hline PAS-1 & $1.92 \mathrm{ab}^{\mathrm{z}}$ & $3.58 \mathrm{~b}$ & $0.58 \mathrm{a}$ & $3.18 \mathrm{~b}$ & $1.67 \mathrm{ab}$ & $0.00 \mathrm{a}$ \\
PAS-2 & $3.50 \mathrm{~b}$ & $2.33 \mathrm{ab}$ & $0.45 \mathrm{a}$ & $1.67 \mathrm{ab}$ & $0.89 \mathrm{ab}$ & $0.00 \mathrm{a}$ \\
PAS-3 & $2.50 \mathrm{ab}$ & $3.75 \mathrm{~b}$ & $1.91 \mathrm{ab}$ & $2.18 \mathrm{ab}$ & $1.27 \mathrm{ab}$ & $0.00 \mathrm{a}$ \\
PAS-4 & $2.92 \mathrm{~b}$ & $3.55 \mathrm{~b}$ & $2.57 \mathrm{~b}$ & $4.60 \mathrm{~b}$ & $4.18 \mathrm{~b}$ & $0.00 \mathrm{a}$ \\
CW $^{\mathrm{y}}$ & $3.83 \mathrm{~b}$ & $4.67 \mathrm{~b}$ & $3.17 \mathrm{~b}$ & $5.00 \mathrm{~b}$ & $3.83 \mathrm{~b}$ & $0.00 \mathrm{a}$ \\
\hline
\end{tabular}

${ }^{\mathrm{z}}$ Different letters in rows indicate significant differences according to Tukey test $(P<0.05)$.

${ }^{\mathrm{y}} \mathrm{CW}=$ California Wonder (susceptible control).

${ }^{\mathrm{x}}$ Uninoculated control.

PAS-2 registered similar results against MX-2, MX-7, MX-8, and MX-10, as did PAS-3 against MX-1, MX-7, MX-8, and MX-10. Additionally, with these treatments, higher percentages of resistant plants were found. Therefore, these cultivars were considered moderately tolerant, tolerant, and moderately resistant against the virulence phenotype evaluated (Table 4). The plants with severity levels of 1 and 2 showed slow disease progression.

According to the plant cultivar categorization criteria (R, MR, T, MT, and S), 11 combinations of cultivar $\times$ phenotype were not susceptible; the remainder had less than 33\% of resistant plants (Table 4, Fig. 1). The pathogen was re-isolated from roots of infected plants with a severity level of 1 .

\section{Discussion}

The present study shows the necessity of evaluating local chile pepper cultivars against characterized. The analysis of disease severity caused by the pathogen in the cultivars of pasilla chile pepper showed variations in the virulence phenotypes of $P$. capsici previously

response. A variation in the response to isolates by cultivars of pepper was also reported by Byung-Soo et al. (2010) in South Korea, where cultivars of pepper tolerant to isolate $\mathrm{Pc003}$ were susceptible to isolate Pc002. In Mexico, Morán-Bañuelos et al. (2010) also reported differences in the severity of $P$. capsici, which was attributable to the genetic variation of 29 native pepper populations from southern Puebla. In Mexico, different levels of resistance to $P$. capsici in 15 out of 32 landraces (C. annuum and C. pubescens) from 14 states were recently reported. Furthermore, the 32 landraces showed disease symptoms, but the severity was variable, with six landraces showing a high level of resistance (RetesManjarrez et al., 2020). However, in South Korea, Su-Jung et al. (2014) observed that resistance in pepper cultivars depends on the inoculum concentration and virulence of the isolate. They evaluated 100 commercial cultivars of pepper against four isolates of $P$. capsici with two inoculum concentrations under controlled conditions. Their cultivars were tolerant to $1.5 \times 10^{4}$ zoospores $/ \mathrm{mL}$ but susceptible when the concentration increased to

Table 4. Categorization of the pasilla pepper cultivars into resistant, moderately resistant, tolerant, moderately tolerant and susceptible according to the number of resistant plants (severity $=0$ ) of each treatment.

\begin{tabular}{|c|c|c|c|c|c|c|}
\hline Cultivar & $\begin{array}{l}\text { Virulence } \\
\text { phenotype }\end{array}$ & $\begin{array}{l}\text { Inoculated } \\
\text { plants }\end{array}$ & $\begin{array}{c}\text { Resistant } \\
\text { plants }\end{array}$ & $\begin{array}{l}\text { Resistant } \\
\text { plants (\%) }\end{array}$ & Classification $^{\mathrm{z}}$ & Mean severity \\
\hline \multirow{5}{*}{ PAS-1 } & MX-1 & 12 & 5 & 42 & $\mathrm{~T}$ & 1.92 \\
\hline & MX-2 & 12 & 2 & 17 & $\mathrm{~S}$ & 3.58 \\
\hline & MX-7 & 12 & 9 & 75 & MR & 0.58 \\
\hline & MX-8 & 12 & 2 & 17 & $\mathrm{~S}$ & 3.18 \\
\hline & MX-10 & 12 & 7 & 58 & $\mathrm{~T}$ & 1.67 \\
\hline \multirow{5}{*}{ PAS-2 } & MX-1 & 12 & 1 & 8 & $\mathrm{~S}$ & 3.50 \\
\hline & MX-2 & 12 & 5 & 42 & $\mathrm{~T}$ & 2.33 \\
\hline & MX-7 & 10 & 9 & 90 & MR & 0.45 \\
\hline & MX-8 & 12 & 7 & 58 & $\mathrm{~T}$ & 1.67 \\
\hline & MX-10 & 9 & 5 & 56 & $\mathrm{~T}$ & 0.89 \\
\hline \multirow{5}{*}{ PAS-3 } & MX-1 & 12 & 4 & 33 & MT & 2.50 \\
\hline & MX-2 & 12 & 0 & 0 & $\mathrm{~S}$ & 3.75 \\
\hline & MX-7 & 11 & 5 & 45 & $\mathrm{~T}$ & 1.91 \\
\hline & MX-8 & 11 & 4 & 36 & MT & 2.18 \\
\hline & MX-10 & 11 & 5 & 45 & $\mathrm{~T}$ & 1.27 \\
\hline \multirow{5}{*}{ PAS-4 } & MX-1 & 12 & 3 & 25 & $\mathrm{~S}$ & 2.92 \\
\hline & MX-2 & 11 & 1 & 9 & $\mathrm{~S}$ & 3.55 \\
\hline & MX-7 & 7 & 2 & 29 & $\mathrm{~S}$ & 2.57 \\
\hline & MX-8 & 10 & 0 & 0 & $\mathrm{~S}$ & 4.60 \\
\hline & MX-10 & 11 & 1 & 9 & $\mathrm{~S}$ & 4.18 \\
\hline \multirow{5}{*}{$\mathrm{CW}$} & MX-1 & 6 & 0 & 0 & $\mathrm{~S}$ & 3.83 \\
\hline & MX-2 & 6 & 0 & 0 & $\mathrm{~S}$ & 4.67 \\
\hline & MX-7 & 6 & 0 & 0 & $\mathrm{~S}$ & 3.17 \\
\hline & MX-8 & 6 & 0 & 0 & $\mathrm{~S}$ & 5.00 \\
\hline & MX-10 & 6 & 0 & 0 & $\mathrm{~S}$ & 3.83 \\
\hline
\end{tabular}

HortScience Vol. 56(10) October 2021

$\mathrm{R}=$ resistant; $\mathrm{MR}=$ moderately resistant; $\mathrm{T}=$ tolerant; $\mathrm{MT}=$ moderately tolerant; $\mathrm{S}=$ susceptible.
$1.5 \times 10^{6}$ zoospores $/ \mathrm{mL}$. In the present study, using a typical concentration of $1 \times 10^{4}$ zoospores/mL helped to classify our Pasilla cultivars and the susceptible control $(\mathrm{CW})$ as $\mathrm{R}$, $\mathrm{MR}, \mathrm{T}, \mathrm{MT}$ or S; however it is necessary to confirm the results and verify the low levels of infection observed in pasilla peppers against more $P$. capsici isolates.

The slow progression of disease shown by our study is consistent with that during breeding studies of Cicer arietinum cultivars against wilting caused by Fusarium oxysporum f. sp. pisi, a term called slow wilting resistance, which is used to describe a slow rate of disease development before reaching $100 \%$ damage (Halila et al., 2010; Jiménez-Díaz et al., 2015; Sharma and Muehlbauer 2007). The search for resistance or tolerance via slow wilting in certain host-pathogen interactions could be promising for the development of cultivars with a greater tolerance spectrum; however, additional evaluations are required to determine if slow wilting allows the harvesting of healthy fruits to obtain competitive yields.

Exploring and screening more genetic resources of cultivated Capsicum from Mexico is a priority for identifying plant material with promising levels of resistance and tolerance to populations of virulence phenotypes of $P$. capsici. The cultivars PAS-1, PAS-2, and PAS-3 were moderately tolerant as well as tolerant and moderately resistant, depending on the virulence phenotype against which they were evaluated. The presence of resistant and susceptible plants in the same cultivar could be attributable to genetic segregation within cultivars of pasilla pepper (Candole et al., 2012).

At present, the Mexican landrace of Capsicum annuum cultivar CM-334 from the state of Morelos is the main source of resistance to $P$. capsici, regardless of the aggressiveness of the isolate or environmental conditions (Castro-Rocha et al., 2012; Sy et al., 2008). Unfortunately, CM334 has undesirable agronomic characteristics and the resistance of CM334 is partially inherited; therefore, no commercial cultivars of chile pepper are currently available with universal resistance to this pathogen (Glosier et al., 2008; Oelke et al., 2003). It has been shown that some Mexican landraces of pepper are MR or T to virulent isolates of $P$. capsici (Ortega et al., 1991). In a recent study, Palma-Martínez et al. (2017) found cultivars of chile serrano and chile huacle with dominant genes of resistance to $P$. capsici. Subsequently, these accessions showed resistance to 10 isolates of $P$. capsici from different pepper production regions of Mexico (GómezRodríguez et al., 2017); however, it is unknown if these isolates belong to different virulence phenotypes. However, Anaya-López et al., (2011) found resistance to P. capsici isolates in the accessions BG102 and BG107 from the INIFAP germplasm bank of Mexico. Candole et al. (2010) evaluated six isolates of $P$. capsici from Georgia on 2301 pepper accessions and found that two accessions from Mexico, PI 201237 and PI640532, consistently showed high levels of resistance. Recently, Retes-Manjarrez et al. (2020) identified new sources of resistance in 14 landraces of piquin, 

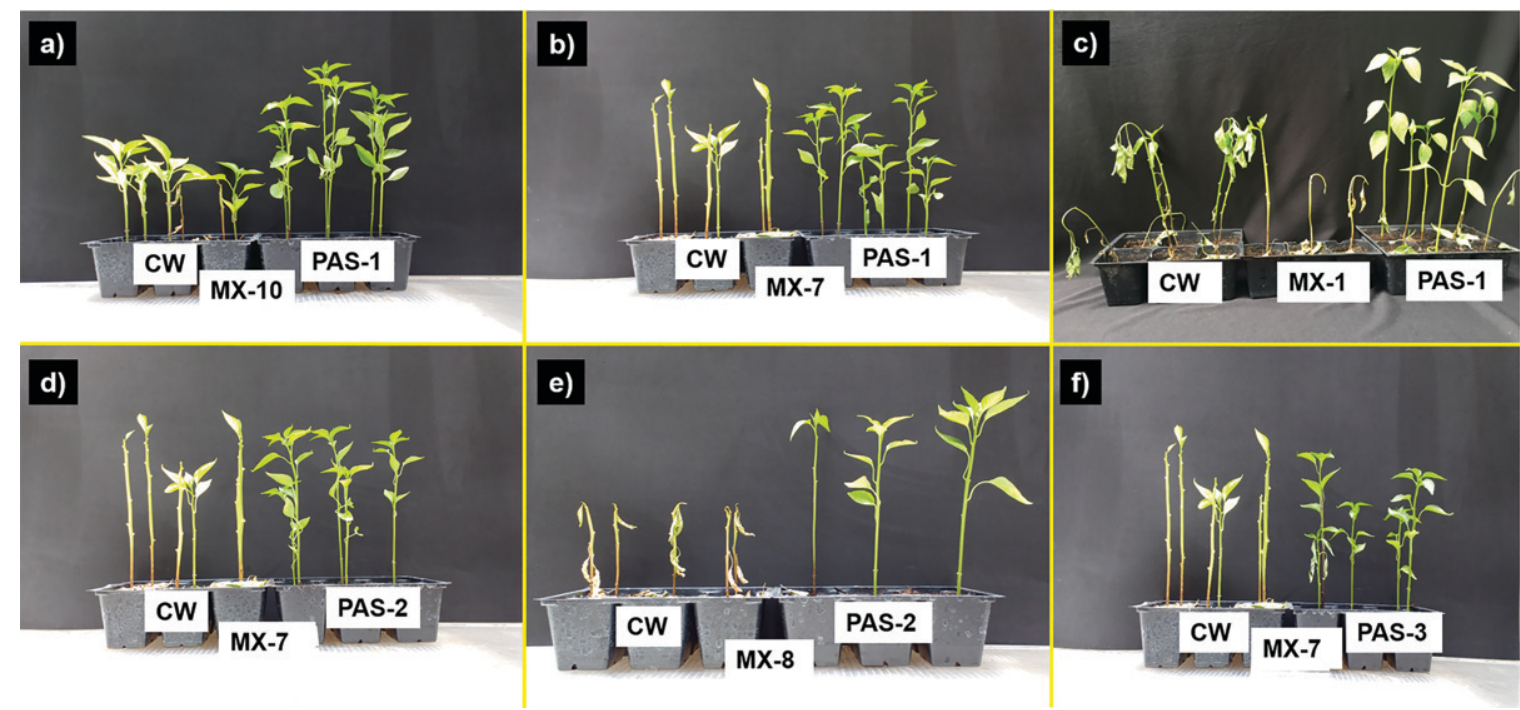

Fig. 1. Severity of Phytophthora blight on three pasilla cultivars (PAS-1, PAS-2, and PAS-3) with the highest percentage of resistant plants after inoculation with four virulence phenotypes of Phytophthora capsici (MX1, MX7, MX8, and MX10).

manzano, pasilla, cola de rata, and jalapeño peppers. Similarly, genotypes of $C$. annuum with resistance to $P$. capsici have been reported in the United States (in New York and Michigan), Laos, and South Korea (Dunn et al., 2014; Foster and Hausbeck 2010; Mo et al., 2014; Su-Jung et al., 2014). A common problem among resistant pepper genotypes is that they show less resistance when assayed under different environmental conditions and $P$. capsici isolates (Dunn and Smart 2015; Messaouda et al., 2015). This is largely explained by the presence of different virulence phenotypes of the pathogen (Oelke et al., 2003; Sy et al., 2008). Therefore, the search for specific resistance to local virulence phenotypes is the best way to generate resistant pepper cultivars. The identification of local pathotypes of $P$. capsici should be part of this strategy. The pasilla pepper cultivars PAS-1, PAS-2, and PAS-3 could be used directly by producers in commercial fields, and they also have the potential to be used in plant breeding programs as sources of genetic tolerance and moderate resistance in the form of slow wilting against local pathotypes of $P$. capsici. One of the shortcomings of the present study was the necessity to evaluate a large group of virulence phenotypes against the local cultivars because it is possible to find their great diversity in the field (Reyes-Tena et al., 2019). However, this pioneering work searched for virulence phenotype-specific resistance of chile pepper cultivars.

\section{Literature Cited}

Aguilar-Meléndez, A., P.L. Morrell, M.L. Roose, and K. Seung-Chul. 2009. Genetic diversity and structure in semiwild and domesticated chiles (Capsicum annuum; Solanaceae) from Mexico. Amer. J. Bot. 96:1190-1202, doi: 10.3732/ ajb.0800155.

Aguilar-Rincón, V.H., T. Corona-Torres, P. LópezLópez, L. Latournerie-Moreno, M. RamírezMeraz, H. Villalón-Mendoza, and J.A. AguilarCastillo. 2010. Los chiles de México y su distribución. SINAREFI, Colegio de Postgraduados,
INIFAP, IT-Conkal, UANL, UAN. Montecillo, Texcoco, Estado de México. <http://www. scielo.org.mx/scielo.php?script=sci_arttext\&pid $=$ S0187-73802011000100002 > .

Anaya-López, J.L., M.M. González-Chavira, E. Villordo-Pineda, R. Rodríguez-Guerra, R. Rodríguez-Martínez, R.G. Guevara-González, L. Guevara-Olvera, V. Montero-Tavera, and I. Torres-Pacheco. 2011. Selection of chili pepper genotypes resistant to pathogenic wilt disease complex. REMEXCA 2:373-383.

Barchenger, D.W., K.H. Lamour, S. Zong-Ming, S. Shrestha, S. Kumar, L. Shih-Wen, R. Burlakoti, and P.W. Bosland. 2017. Intra- and intergenomic variation of ploidy and clonality characterize Phytophthora capsici on Capsicum sp. in Taiwan. Mycol. Prog. 16:955-963, doi: 10.1007/ s11557-017-1330-0.

Barchenger, D.W., K.H. Lamour, and P.W. Bosland. 2018a. Challenges and strategies for breeding resistance in Capsicum annuum to the multifarious pathogen, Phytophthora capsici. Front. Plant Sci. 9:1-16, doi: 10.3389/fpls.2018.00628.

Barchenger, D.W., Z.M. Sheu, S. Kumar, W.S. Lin, R.R. Burlakoti, and P.W. Bosland. 2018b. Race characterization of Phytophthora root rot on Capsicum in Taiwan as a basis for anticipatory resistance breeding. Phytopathology 108:964-971, doi: 10.1094/PHYTO-08-17-0289-R.

Bi, Y., J. Hu, X. Cui, J. Shao, X. Lu, Q. Meng, and X. Liu. 2014. Sexual reproduction increases the possibility that Phytophthora capsici will develop resistance to dimethomorph in China. Plant Pathol. 63:1365-1373, doi: 10.1111/ ppa. 12220.

Byung-Soo, K., K. Tae-Ryong, H. Ji-Eun, L. Jae-Moo, P. Dong-Guen, A. Joon-Hyung, and K. Hye-Yeon. 2010. Resistant to Phytophthora blight of commercial pepper cultivars in Korea. Singmulbyeong Yeon-gu 16:141-147, doi: 10.5423/RPD.2010.16.2.141.

Candole, B.L., P.J. Conner, and P. Ji. 2010. Screening Capsicum annuum accessions for resistance to six isolates of Phytophthora capsici. HortScience 45:254-259, doi: 10.21273/ HORTSCI.45.2.254.

Candole, B.L., P.J. Conner, C. McGregor, V. Waters, and P. Ji. 2012. The disease reactions of heirloom bell pepper "California Wonder" to Phytophthora capsici. Agr. Sci. 3:417-424, doi: 10.4236/as.2012.33049.
Castro-Rocha, A., S.P. Fernández-Pavía, and P. Osuna-Ávila. 2012. Mecanismos de defensa del chile en el patosistema Capsicum annuum Phytophthora capsici. Rev. Mex. Fitopatol. 30:49-65.

Castro-Rocha, A., S. Shrestha, B. Lyon, G.L. Grimaldo-Pantoja, J.P. Flores-Marges, J. ValeroGalván, M. Aguirre-Ramírez, P. Osuna-Ávila, N. Gómez-Dorantes, G. Ávila-Quezada, J.J. Luna-Ruíz, G. Rodríguez-Alvarado, S.P. Fernández-Pavía, and K. Lamour. 2016. An initial assessment of genetic diversity for Phytophthora capsici in northern and central Mexico. Mycol. Prog. 15:15, doi: 10.1007/s11557-0161157-0.

Dunn, A.R., H.W. Lange, and C.D. Smart. 2014. Evaluation of commercial bell pepper cultivars for resistance to Phytophthora blight (Phytophthora capsici). Plant Health Prog. 15:19-24, doi: 10.1094/PHP-RS-13-0114.

Dunn, A.R. and C.D. Smart. 2015. Interactions of Phytophthora capsici with resistant and susceptible pepper roots and stems. Phytopathology 105:1355-1361, doi: 10.1094/PHYTO-02-150045-R.

Foster, J.M. and M.K. Hausbeck. 2010. Resistance of pepper to Phytophthora crown, root, and fruit rot is affected by isolate virulence. Plant Dis. 94:24-30, doi: 10.1094/PDIS-94-1-0024.

Glosier, B.R., E.A. Ogundiwin, G.S. Sidhu, D.R. Sischo, and J.P. Prince. 2008. A differential series of pepper (Capsicum annuum) lines delineates fourteen physiological races of Phytophthora capsici. Euphytica 162:23-30, doi: 10.1007/s10681-007-9532-1.

Gómez-Rodríguez, O., T. Corona-Torres, and V.H. Aguilar-Rincón. 2017. Differential response of pepper (Capsicum annuum L.) lines to Phytophthora capsici and root-knot nematodes. Crop Prot. 92:148-152, doi: 10.1016/j.cropro.2016. 10.023.

Halila, I., J. Rubio, T. Millán, J. Gil, M. Kharrat, and M. Marrakchi. 2010. Resistance in chickpea (Cicer arietinum) to Fusarium wilt race '0'. Plant Breed. 129:563-566, doi: 10.1111/ j.1439-0523.2009.01703.x.

Jiang, L., S. Sanogo, and P.W. Bosland. 2015. Using Recombinant Inbred Lines to monitor changes in the race structure of Phytophthora capsici in chile pepper in New Mexico. Plant 
Health Prog. 16:235-240, doi: 10.1094/PHPRS-15-0034.

Jiménez-Díaz, R.M., P. Castillo, M.M. JiménezGasco, B.B. Landa, and J.A. Nava-Cortés. 2015. Fusarium wilt of chickpeas: Biology, ecology and management. Crop Prot. 73:16-27, doi: 10.1016/j.cropro.2015.02.023.

Lamour, K.H., J. Mudge, D. Gobena, O.P. HurtadoGonzales, J. Schmutz, A. Kuo, N.A. Miller, B.J. Rice, S. Raffaele, L.M. Cano, A.K. Bharti, R.S. Donahoo, S. Finley, E. Huitema, J. Hulvey, D. Platt, A. Salamov, A. Savidor, R. Sharma, R. Stam, D. Storey, M. Thines, J.B. Win, J. Haas, D.L. Dinwiddie, J. Jenkins, J.R. Knight, J.P. Affourtit, C.S. Han, O. Chertkov, E.A. Lindquist, C. Detter, I.V. Grigoriev, S. Kamoun, and S.F. Kingsmore. 2012a. Genome sequencing and mapping reveal loss of heterozygosity as a mechanism for rapid adaptation in the vegetable pathogen Phytophthora capsici. Mol. Plant Microbe Interact. 25:1350-1360, doi: 10.1094/MPMI-0212-0028-R

Lamour, K.H., R. Stam, J. Pupe, and E. Huitema. 2012b. The oomycete broad-host-range pathogen Phytophthora capsici. Mol. Plant Pathol. 13:329-337, doi: 10.1111/j.1364-3703.2011. 00754.x.

Leonian, L.H. 1922. Stem and fruit blight of peppers caused by Phytophthora capsici. Phytopathology 12:401-408.

Macías-Valdez, L., M.E. Baltazar-Brenes, E. González-Gaona, C. Serrano-Gómez, M.A. Galindo-Reyes, L.H. Maciel-Pérez, and F.J. Robles-Escobedo. 2010. Nueva tecnología de manejo para el control de la marchitez del chile en Aguascalientes. INIFAP, Aguascalientes, Mexico. <https://es.scribd.com/document/2431 70083/Nueva-Tecnologia-de-Manejo-Para-ElControl-de-La-Marchitez-Del-Chile-en-Aguas calientes $>$.

Messaouda, B., G. Abdelhadi, and M. Samia. 2015. Susceptibility of Algerian pepper cultivars (Capsicum annuum L.) to Phytophthora capsici strains from different geographic areas. Afr. J. Biotechnol. 14:3011-3018, doi: 10.5897/ AJB2015.14853.

Mo, H., S. Kim, K.P.P. Wai, M.I. Siddique, H. Yoo, and K. Byung-Soo. 2014. New sources of resistance to Phytophthora capsici in Capsicum spp. Hort. Environ. Biote. 55:50-55, doi: 10.1007/s13580-014-0016-7.

Monroy-Barbosa, A. and P.W. Bosland. 2010. A rapid technique for multiple-race disease screening of Phytophthora foliar blight on single Capsicum annuum L. plants. HortScience 45: 1563-1566, doi: 10.21273/HORTSCI.45.10.1563.

Monroy-Barbosa, A. and P.W. Bosland. 2011. Identification of novel physiological races of Phytophthora capsici causing foliar blight using the New Mexico Recombinant Inbred pepper Lines set as a host differential. J. Amer. Soc. Hort. Sci. 136:205-210, doi: 10.21273/ JASHS.136.3.205.

Morán-Bañuelos, S.H., V.H. Aguilar-Rincón, T. Corona-Torres, and E. Zavaleta-Mejía. 2010. Resistencia a Phytophthora capsici Leo. de chiles nativos del sur de Puebla, México. Rev. Fitotec. Mex. 33:21-26, doi: 10.35196/rfm.2010. Especial_4.21.

Muñoz, Z.R. 2000. Diccionario enciclopédico de gastronomía mexicana. Clio, México.

Oelke, L.M., P.W. Bosland, and R. Steiner. 2003. Differentiation of race specific resistance to Phytophthora root rot and foliar blight in Capsicum annuum. J. Amer. Soc. Hort. Sci. 128:213-218, doi: 10.21273/JASHS.128.2.0213.

Ortega, R.G., C.P. Español, and J.C. Zueco. 1991. Genetics of resistance to Phytophthora capsici in the pepper line 'SCM-334'. Plant Breed. 107:50-55, doi: 10.1111/j.1439-0523.1991.tb00 527.x.

Palma-Martínez, E., V.H. Aguilar-Rincón, T. Corona-Torres, and O. Gómez-Rodríguez. 2017. Resistencia a Phytophthora capsici Leo en líneas de chile huacle (Capsicum annuum L.). Rev. Fitotec. Mex. 40:359-363, doi: 10.35196/rfm.2017.3.359-363.

Retes-Manjarrez, J.E., W.A. Rubio-Aragón, I. Márques-Zequera, I. Cruz-Lachica, R.S. García-Estrada, and O. Sy. 2020. Novel sources of resistant to Phytophthora capsici on pepper (Capsicum sp.) landraces from Mexico. Plant Pathol. J. 36:600-607, doi: 10.5423/ PPJ.OA.07.2020.0131.

Reyes-Tena, A., A. Castro-Rocha, G. RodríguezAlvarado, G. Vázquez-Marrufo, M.E. Pedraza-
Santos, K. Lamour, J. Larsen, and S.P. FernándezPavía. 2019. Virulence phenotypes on chili pepper for Phytophthora capsici isolates from Michoacán, Mexico. HortScience 54:15261531, doi: 10.21273/HORTSCI13964-19.

Reyes-Tena, A., G. Rodríguez-Alvarado, S.P. Fernández-Pavía, M.E. Pedraza-Santos, J. Larsen, and G. Vázquez-Marrufo. 2020. Morphological characterization of Phytophthora capsici isolates from Jalisco and Michoacán, Mexico. Rev. Mex. Fitopatol. 39:75-93, doi: 10.18781/R.MEX.FIT.2007-5.

Ribeiro, C.S.C. and P.W. Bosland. 2012. Physiological race characterization of Phytophthora capsici isolates from several host plant species in Brazil using New Mexico Recombinant Inbred Lines of Capsicum annuит at two inoculum levels. J. Amer. Soc. Hort. Sci. 137:421-426, doi: 10.21273/JASHS.137.6.421.

Rincón, V.H.A., T.C. Torres, P.L. López, L.L. Moreno, M.R. Meraz, H.V. Mendoza, and J.A.A. Castillo. 2010. Los chiles de México y su distribución. SINAREFI.

Secretaría de Agricultura y Desarrollo Rural. 2020. Servicio de información agroalimentaria y pesquera. $<$ https://www.gob.mx/siap $>$.

Sharma, K.D. and F.J. Muehlbauer. 2007. Fusarium wilt of chickpea: Physiological specialization, genetics of resistance and resistance gene tagging. Euphytica 157:1-14, doi: 10.1007/ s10681-007-9401-y.

Silva-Rojas, H.V., S.P. Fernández-Pavía, C.B. Góngora-Canul, C. Macías-López, and G.D. Ávila-Quezada. 2009. Distribución espacio temporal de la marchitez del chile (Capsicum annuum L.) en Chihuahua e identificación del agente causal Phytophthora capsici Leo. Rev. Mex. Fitopatol. 27:134-147.

Su-Jung, J., S. Sun-Ah, S.J. Kyoung, H.C. Yong, K. Jin-Cheol, and J.C. Gyung. 2014. Resistance of chili pepper cultivars to isolates of Phytophthora capsici. Korean J. Hort. Sci. 32:66-76, doi: 10.7235/hort.2014.13079.

Sy, O., R. Steiner, and P.W. Bosland. 2008. Recombinant inbred line differential identifies race-specific resistance to Phytophthora root rot in Capsicum annuum. Phytopathology 98:867-870, doi: 10.1094/PHYTO-98-8-0867. 